\title{
On the Origin of the Pastorals' Authenticity Criticism: A "New" Perspective
}

\section{JERMO VAN NES}

Evangelische Theologische Faculteit, Sint Jansbergsesteenweg 95, 3001, Leuven, Belgium;

Theologische Universiteit, Broederweg 15, 8261GS, Kampen, the Netherlands.

email: jermo.vannes@etf.edu

It is generally agreed among contemporary scholars that the modern critique on the authorship claim of the New Testament letters addressed to Timothy and Titus originated in early nineteenth-century Germany with the studies of Schmidt and Schleiermacher on 1 Timothy. However, a late eighteenth-century study by the British clergyman Edward Evanson challenges this consensus as it proves Titus to have been suspect of pseudonymity before. This "new" perspective found in Evanson's neglected source also nuances the common assumption that from its very beginnings the critical campaign against the letters' authenticity was mainly driven by linguistic considerations. ${ }^{1}$

Keywords: Pastoral Epistles/Pastorals, 1 Timothy, Titus, authorship, Edward Evanson

The academic study of the New Testament epistles addressed to Timothy and Titus, collectively known as the Pastoral Epistles (PE) or simply Pastorals, ${ }^{2}$ continues to be dominated

\footnotetext{
${ }^{1}$ This article was written in the capacity of research associate in the department of New Testament studies at the University of Pretoria, South Africa. Thanks are due to Prof. Dr. Martin Webber for correcting the English text and to Astrid Ooms for preparing its format.

${ }^{2}$ P. H. Towner in his commentary The Letters to Timothy and Titus (NICNT; Grand Rapids, MI: Eerdmans, 2006) 88-9 asked to say farewell to the term "pastoral epistles" for 1-2 Timothy and Titus, but M. Winter ('Die
} 
by the question of authorship. ${ }^{3}$ With regards to the origin of this debate, the following assumptions are usually taken for granted by scholars:

“Pastoralbriefe" - ihr Name im Licht der popular-philosophischen Seelenleitung', KD 59.4 (2013) 232-50) has recently shown that the overall pastoral intention of the letters is very similar to the psychagogic method found in writings of contemporaneous popular philosophers, which allows for a pastoral designation.

${ }^{3}$ See the recent discussions and various authorship hypotheses offered by, for instance, J. D. Miller, The Pastoral Letters as Composite Documents (SNTSMS 93; Cambridge: Cambridge University Press, 1997); W. A. Richards, Difference and Distance in Post-Pauline Christianity: An Epistolary Analysis of the Pastorals (SBL 44; New York: Lang, 2002); R. Fuchs, Unerwartete Unterschiede. Müssen wir unsere Ansichten über die Pastoralbriefe revidieren? (BM 12; Wuppertal: Brockhaus, 2003); A. Merz, Die fiktive Selbstauslegung des Paulus. Intertextuelle Studien zur Intention und Rezeption der Pastoralbriefe (NTOA 52; Göttingen: Vandenhoeck \& Ruprecht, 2004); R. Riesner, 'Once More: Luke-Acts and the Pastoral Epistles', History and Exegesis (ed. S.-W. Son; New York/London: T\&T Clark, 2006) 239-58; J. W. Aageson, Paul, the Pastoral Epistles, and the Early Church (LPS; Peabody, MA: Hendrickson, 2008); K. P. Donfried, ed., 1 Timothy Reconsidered (COP 18; Leuven: Peeters, 2008) 19-62; M. Klinker-de Klerck, 'The Pastoral Epistles: Authentic Pauline Writings', EJT 17 (2008) 101-8; T. Glaser, Paulus als Briefroman erzählt. Studien zum antiken Briefroman und seiner christlichen Rezeption in den Pastoralbriefen (NTOA 76; Göttingen: Vandenhoeck \& Ruprecht, 2009); J. Herzer, 'Fiktion oder Täuschung? Zur Diskussion über die Pseudepigraphie der Pastoralbriefe', Pseudepigraphie und Verfasserfiktion in frühchristlichen Briefen (ed. J. Frey et al.; WUNT 246; Tübingen: Mohr Siebeck, 2009), 489-536; A. J. Köstenberger and T. L. Wilder, eds., Entrusted with the Gospel: Paul's Theology in the Pastoral Epistles (Nahsville, TN: Broadman \& Holman, 2010);

M. Tsuji, 'Persönliche Korrespondenz des Paulus: Zur Strategie der Pastoralbriefe als Pseudepigrapha', NTS 56 (2010) 253-72; C. L. Westfall, ‘A Moral Dilemma? The Epistolary Body of 2 Timothy', Paul and the Ancient Letter Form (ed. S. E. Porter and S. A. Adams; PAST 6; Leiden/Boston: Brill, 2010) 213-52; J. Luttenberger, Prophetenmantel oder Bücherfutteral? Die persönlichen Notizen in den Pastoralbriefen im Licht antiker Epistolographie und literarischer Pseudepigraphie (ABG 40; Leipzig: Evangelische Verlagsanstalt, 2012 ); B. D. Ehrman, Forgery and Counterforgery: The Use of Literary Deceit in Early Christian Polemics (New York: Oxford University Press, 2013) 192-222, 367-84. 
(1) Prior to the nineteenth century none of the PE had ever been questioned on their claim to Pauline authorship (cf. 1 Tim 1.1; 2 Tim 1.1; Tit 1.1). Exceptions include Marcion (c. 85160), Basilides (fl. c. 117-161), and Tatian (c. 120-180), all of whom are said to have "rejected" (recusaverit) the epistles to Timothy (cf. Clement of Alexandria, Strom. 2.11) and Titus (cf. Tertullian, Marc. 5.21; Epiphanius, Pan. 42.9.3-4). The exact reason for their doing so will probably remain an open question, ${ }^{4}$ but Jerome states in the preface of his commentary on Titus that the rationale was arbitrary rather than critical in nature: 'cum haeretica auctoritate pronuntient et dicant: "Illa epistula Pauli est, haec non est"., 5

(2) The debate concerning the (non-)Pauline authorship of the PE originated with two German studies on 1 Timothy by Johann Ernst Christian Schmidt in $1804^{6}$ and Friedrich Daniel Ernst Schleiermacher in $1807 .{ }^{7}$ Because Schmidt only hinted at some interpretative difficulties without explicitly denying the apostolic origin of 1 Timothy, Schleiermacher is usually referred

\footnotetext{
${ }^{4}$ Given the PE's absence in $\mathfrak{P}^{46}$, some scholars (e.g. L. M. McDonald, The Biblical Canon: Its Origin, Transmission, and Authority (Peabody, MA: Hendrickson, 2007) 368) conjecture that they were unknown to heterodox teachers by the mid-second century CE. Others (e.g. L. T. Johnson, Letters to Paul's Delegates: 1 Timothy, 2 Timothy, Titus (NTC; Valley Forge, PA: Trinity Press International, 1996) 23-4), however, argue that the letters were rejected deliberatively because not all of their contents paralleled Gnostic teaching (cf. Tertullian, Marc. 5.21).

${ }^{5}$ F. Bucchi, ed., Hieronymi Presbyteri Commentariorum in Epistolam Pauli Apostoli ad Titum (CCSL 77C; Turnhout: Brepols, 2003) 3.

${ }^{6}$ J. E. C. Schmidt, Historisch-kritische Einleitung in's Neue Testament (Giessen: Tasche \& Müller, 1804) 259-61.

${ }^{7}$ F. D. E. Schleiermacher, Ueber den sogenannten ersten Brief des Paulos an den Timotheos. Ein kritisches Sendschreiben an J.C. Gass (Berlin: Realschulbuchhandlung, 1807).
} 
to as the first scholar ever rejecting its Pauline authorship prior to the overall critique offered by Johann Gottfried Eichhorn in his New Testament introduction dating from $1812{ }^{8}$

(3) Accordingly, the critical campaign against the Pastorals' authenticity is generally said to have been ignited by linguistic considerations as these comprised the bulk of Schleiermacher's argument. Examples include 1 Timothy's comparatively large amount of hapax legomena, unPauline semantic deviations, and stylistic idiosyncrasies.

Each of these common assumptions is echoed widely in (dictionary) articles, ${ }^{9}$ monographs, ${ }^{10}$ commentaries, ${ }^{11}$ and New Testament introductions on the Pastorals. ${ }^{12}$ It seems,

\footnotetext{
${ }^{8}$ J. G. Eichhorn, Einleitung in das Neue Testament (3 vols.; Leipzig: Weidmann, 1803-1814) III.1.315-410. It is mistaken, as does e.g. Ehrman (Forgery, 192), to credit Herzer (Fiktion, 489-536) for pointing out Schmidt's pioneering work. It was recognized as such by e.g. Schleiermacher (Timotheos, 21-2) and J. F. Beckhaus (Specimen observationum critico-exegeticarum de vocabulis $\dot{\alpha} \pi \alpha \xi \lambda \varepsilon \gamma о \mu \varepsilon \dot{\varepsilon}{ }^{\prime} \iota_{\zeta}$ et rarioribus dicendi formulis in prima ad Timotheum epistola Paulina obviis, authentiae ejus nihil detrahentibus (Linz: Jülicher, 1810) 4-5) long before him. ${ }^{9}$ E.g. W. Schenk, 'Die Briefe an Timotheus I und II und an Titus (Pastoralbriefe) in der neueren Forschung (19451985)', ANRW (Berlin/New York: De Gruyter, 1987) II.25.4.3407; J. Roloff, 'Pastoralbriefe', TRE (Berlin/New York: De Gruyter, 1996), 26.51; R. F. Collins, 'Pastoralbriefe', RGG (Tübingen: Mohr Siebeck, 2003 ) 6.989; J. Herzer, 'Abschied vom Konsens? Die Pseudepigraphie der Pastoralbriefe als Herausforderung an die neutestamentliche Wissenschaft', TLZ 129 (2004) 1267; I. H. Marshall, 'The Pastoral Epistles', S. Westerholm, ed., The Blackwell Companion to Paul (Malden, MA/Oxford: Wiley-Blackwell, 2011) 108.

${ }^{10}$ E.g. Y. Redalié, Paul après Paul. Le temps, le salut, la morale selon les épîtres à Timothée et à Tite (MdB 31; Genève: Labor et Fides, 1994) 14; M. Harding, Tradition and Rhetoric in the Pastoral Epistles (SBL 3; New York: Lang, 1998) 8; N. Casalini, Parole alla Chiesa. La tradizione Paolina nelle Lettere Pastorali (SBF; Milano: ETS, 2009) 39; J. Twomey, The Pastoral Epistles Through the Centuries (BBC; Malden, MA/Oxford: Wiley-Blackwell, 2009) 226; M. M. Yarbrough, Paul's Utilization of Preformed Traditions in 1 Timothy: An Evaluation of the Apostle's Literay, Rhetorical, and Theological Tactics (LNTS 417; London/New York: T\&T Clark, 2009) 1 n. 2; M.
} 
however, that not many scholars have been aware of a book entitled The Dissonance of the Four Generally Received Evangelists, and the Evidence of their Respective Authenticity Examined by the British clergyman Edward Evanson (1731-1805). ${ }^{13}$ Using pre-Tübingen tendency criticism,

Engelmann, Unzertrennliche Drillinge? Motivsemantische Untersuchungen zum literarischen Verhältnis der Pastoralbriefe (BZNT 192; Boston/Berlin: De Gruyter, 2012) 10-11.

${ }^{11}$ E.g. G. W. Knight III, The Pastoral Epistles (NIGTC; Grand Rapids, MI: Eerdmans, 1992) 21; C. MarcheselliCasale, Le Lettere Pastorali. Le due lettere a Timoteo e la lettera a Tito (SOC 15; Bologna: EDB, 1995) 22; W. D. Mounce, Pastoral Epistles (WBC 46; Nashville, TN: Nelson, 2000) lxxxiii-lxxxiv; L. T. Johnson, The First and Second Letters to Timothy (AB 35A; New York: Doubleday, 2001) 42-4; L. Oberlinner, Der erste Timotheusbrief, der zweiter Timotheusbrief (HThKNT; Freiburg/Basel/Wien: Herder, 1994-1995; repr. 2002) xxxiii; R. F. Collins, I \& II Timothy and Titus: A Commentary (NTL; Louisville, KY: Westminster John Knox, 2002) 33; A. Weiser, Der zweite Brief an Timotheus (EKKNT XVI/I; Düsseldorf/Zürich/Neukirchen-Vluyn: Benziger/Neukirchener, 2003) 54; P. Iovino, Lettere a Timoteo. Lettera a Tito (ILBNT 15; Milano: Paoline, 2005) 256; Towner, Timothy and Titus, 10; B. Witherington III, A Socio-Rhetorical Commentary on Titus, 1-2 Timothy and 1-3 John, vol. 1 of Letters and Homilies for Hellenized Christians (Downers Grove, IL: InterVarsity, 2006) 51; M. Gourgues, Les deux lettres à Timothée, La lettre à Tite (CbNT 14; Paris: Cerf, 2009) 43.

${ }^{12}$ E.g. Y. Redalié, 'Les épîtres pastorales', Introduction au Nouveau Testament: Son histoire, son écriture, sa théologie (ed. D. Marguerat; Genève: Labor et Fides, $2008^{4}$ ) 329; A. J. Köstenberger, L. S. Kellum, and C. L. Quarles, The Cradle, the Cross, and the Crown: An Introduction to the New Testament (Nashville, TN: Broadman \& Holman, 2009) 638; I. Broer, Einleitung in das Neue Testament (Würzburg: Echter, 2010³) 524; U. Schnelle, Einleitung in das Neue Testament (UTB 1830; Göttingen: Vandenhoeck \& Ruprecht, 20117) 369; E. M. Boring, An Introduction to the New Testament: History, Literature, Theology (Louisville, KY: Westminster John Knox, 2012) 372; D. A. Hagner, The New Testament: A Historical and Theological Introduction (Grand Rapids, MI: Baker, 2012) 614 .

${ }^{13}$ It was noticed by e.g. K. A. Credner, Einleitung in das Neue Testament (Halle: Waisenhaus, 1836) I.1.457-8, but today the book is only referred to in footnotes by not even a handful of scholars, including D. Guthrie, 'The Development of the Idea of Canonical Pseudepigrapha in New Testament Criticism', VE 1 (1962) 44 n. 5; E. E. 
Evanson in this epoch-making study ${ }^{14}$ advocated the pseudonymity of all canonical Gospels except Luke, ${ }^{15}$ Romans, Ephesians, Colossians, Philippians, Titus, Philemon, Hebrews, James, 12 Peter, 1-3 John, Jude, and the seven letters to the Asian churches in the book of Revelation. ${ }^{16}$ Raymond Collins is one of the few scholars who refer to Evanson's work in his historical overview of the Pastorals' authenticity criticism, but he dates it between the studies of Schmidt and Schleiermacher as he relies on a second edition published in $1805 .{ }^{17}$ Its section on Titus is no different from that of the first edition, dating from 1792 , and reads as follows: ${ }^{18}$

In the Epistle to Titus, the very introductory address excites in my mind a strong suspicion, that it was not written by St. Paul; for he calls himself, what he never does in

Ellis, 'Traditions in the Pastoral Epistles', Early Jewish and Christian Exegesis. Studies in Memory of William Hugh Brownlee (ed. C. A. Evans and W. F. Stinespring; Atlanta, GA: Scholars Press, 1987) 248 n. 61; id., The Making of the New Testament Documents (Boston/Leiden: Brill, 2002) 418 n. 62; J. van Nes, 'The Problem of the Pastoral Epistles: An Important Hypothesis Reconsidered', Paul and Pseudepigraphy (ed. S. E. Porter and G. P. Fewster; PAST 8; Leiden/Boston: Brill, 2013) 153 n. 1.

${ }^{14}$ Evanson's theory was the object of concern for no less an occasion than the Bampton lectures as presented by Thomas Falconer at the University of Oxford in 1810, which was later published as Certain Principles in Evanson's “Dissonance of the Four Generally Received Evangelists” Examined (Oxford: Oxford University Press, 1811).

${ }^{15}$ Not Mark, as claimed by J. McClintock and J. Strong, eds., Cyclopaedia of Biblical, Theological, and Ecclesiastical Literature (12 vols.; 1867-94; repr. Grand Rapids, MI: Baker, 1981) 3.372.

${ }^{16}$ For more details about his controversial life and work, see 'Evanson, Edward', Encyclopadia Britannica (29 vols.; New York: EBC, 1910-11 ${ }^{11}$ ) 10.3.

${ }^{17}$ R. F. Collins, Letters That Paul Did Not Write: The Epistle to the Hebrews and the Pauline Pseudepigrapha (GNS 28; Wilmington, DE: Glazier, 1988; repr. Eugene, OR: Wipf \& Stick, 2005) 89.

${ }^{18}$ E. Evanson, The Dissonance of the Four Generally Received Evangelists and the Evidence of Their Respective Authenticity Examined (Ipswich: Jermyn, 1792) 267-9. 
any other Epistle, a servant of God; though to the Galatians, c. iv. v. 6 and 7, he says, "because ye are sons, God hath sent forth the spirit of his son into your hearts, crying Abba Father, wherefore thou art no more a servant but a son, \&c." He adds also, "an Apostle of Jesus Christ" (not by the will of God, as he usually expresses it, but) "according to the faith of God's elect and the acknowledging of the truth," all which, in St. Paul's mouth, is quite a new kind of language. As I proceed my suspicion is greatly confirmed by finding a most malicious, illiberal, national reflection of a Greek Poet upon the moral character of the Cretans quoted by the author, affirmed by him to be true, and the Poet himself denominated a Prophet. Besides, the state of the Church in Crete, as described in the seven last verses of the first chapter, and the direction about heretics, c. iii. v. 10, are much more suitable to the state of the Church in later times, predicted by St. Paul to Timothy, than at any period during the life of St. Paul. The author of the Epistle also, c. iii. v. 3, represents himself and Titus as having, in the former part of their lives, before their conversion to Christianity, been "foolish, disobedient, deceived, serving divers lusts and pleasures, living in malice and envy, hateful, and hating one another." Now when St. Paul enumerates several unchristian immoralities to the Corinthians, he adds, not including himself, nor even the majority of the heathen converts, "and such were some of you; but ye are washed, \&c." And of himself he confidently declared before the Jewish Council, Acts c. xxiii. v. i. "Men and brethren, I have lived in all good conscience before God, until this day."

Whether or not Evanson's study proves convincing for accepting the pseudonymity of Titus, it does prove the inaccuracy of common statements like 'the authenticity of the PE was not 
questioned until the nineteenth century' ${ }^{19}$ or 'J. E. C. Schmidt was the first to question their genuineness. ${ }^{20}$ Not only had the Pauline authorship of Titus been questioned in Britain by the late eighteenth century, both statements also mistakenly assert that the authenticity criticism on 1-2 Timothy and Titus was directed from the beginning at all three writings simultaneously. In fact, there was a span of twenty years between Evanson's individual critique on Titus and Eichhorn's overall critique on the Pastorals including the Timothy correspondence. This should encourage future scholars writing histories of research on the authorship of 1-2 Timothy and Titus to adopt a similar approach as does a growing group of contemporary exegetes, namely to respect the letters' individuality. ${ }^{21}$

It is likewise inaccurate to claim that ' $[\mathrm{t}]$ he genuineness of the Pastorals was first questioned $[\ldots]$ for stylistic and linguistic reasons. ${ }^{22}$ Similar to the studies of Schmidt and Schleiermacher on 1 Timothy, the work of Evanson did not focus exclusively on linguistic peculiarities in Titus. ${ }^{23}$ Some of the issues he touches upon relate to historical matters, like the

\footnotetext{
${ }^{19}$ Mounce, Pastoral Epistles, 1xxxiii.

${ }^{20}$ J. D. James, The Genuineness and Authorship of the Pastoral Epistles (London/New York/Bombay: Longmans \& Green, 1906) 2.

${ }^{21}$ Cf. e.g. M. Prior, Paul the Letter-Writer and the Second Letter to Timothy (JSNTSup 23; Sheffield: JSOT, 1989);
} J. Murphy-O’Connor, '2 Timothy Contrasted with 1 Timothy and Titus', RB 98 (1991) 403-18; Johnson, Delegates; Richards, Difference; Fuchs, Unerwartete Unterschiede; J. Herzer, ‘Abschied vom Konsens?', 1267-82; Towner, Timothy and Titus; Aageson, Paul; Marshall, 'Pastoral Epistles', 110-18; Engelmann, Unzertrennliche Drillinge?. ${ }^{22}$ E. E. Ellis, 'The Authorship of the Pastorals: A Résumé and Assessment of Current Trends', Paul and His Recent Interpreters (Grand Rapids, MI: Eerdmans, 1961; repr. Eugene, OR: Wipf \& Stock, 2004) 49.

${ }^{23}$ Schmidt (Einleitung, 259-61) expressed his doubts about the genuineness of 1 Timothy, mainly because he could not harmonize some of its biographical details with the information given in Acts and Paul's Corinthian correspondence. With regards to Schleiermacher, the bulk of his analysis was literary rather than linguistic (contra 
post-apostolic condition of the Cretan Church and the peculiar profile of the heretics. Others concern the author's self-representation, like his use of pagan materials and incredulous testimony of having lived a sinful pre-Christian life (cf. 1 Cor 6.9-11; Acts 23.1). This suggests that the critical campaign against the Pastorals' authenticity was (probably) initiated by Evanson and extended by Schmidt and Schleiermacher, but from the beginning was multidimensional and cumulative, which has been the case ever since. ${ }^{24}$

Johnson, Timothy, 43). He certainly discussed the peculiar language of 1 Timothy at length (Schleiermacher, Timotheus, 29-104), but the lion's share of his letter-essay concerns historical and literary matters, especially the incoherence and theological inferiority of 1 Timothy in comparison to 2 Timothy and Titus (104-229).

${ }^{24}$ Cf. e.g. Eichhorn, Einleitung, III.1.315-410; F. C. Baur, Die sogenannten Pastoralbriefe des Apostels Paulus aufs neue kritisch untersucht (Stuttgart: Cotta, 1835); E. T. Mayerhoff, Der Brief an die Colosser, mit vohrnehmlicher Berücksichtigung der drei Pastoralbriefe kritisch geprüft (Berlin: Schultze, 1838) 5-6, 11-27, 32-9, 122-36; C. G. Neudecker, Lehrbuch der historisch-kritischen Einleitung in das Neue Testament (Leipzig: Breitkopf \& Härtel, 1840) 542-89; W. M. L. de Wette, Die Einleitung in das Neue Testament enthaltend, vol. 2 of Lehrbuch der historisch-kritischen Einleitung in die Bibel Alten und Neuen Testaments (Berlin: Reimer, 1848 ${ }^{5}$ ) 307-11; B. Bauer, Kritik der paulinischen Briefe (3 vols.; Berlin: Hempel, 1850-52) 3.77-88; A. Hilgenfeld, Historisch-kritische Einleitung in das Neue Testament (Leipzig: Fues, 1875) 744-65; J. E. Huther, Kritisch exegetisches Handbuch über die Briefe an Timotheus und Titus (Göttingen: Vandenhoeck \& Ruprecht, 1876 ${ }^{4}$ ), 53-73; H. J. Holtzmann, Die Pastoralbriefe, kritisch und exegetisch behandelt (Leipzig: Engelmann, 1880) 15-282. The latter is generally said (by e.g. M. Harding, What Are They Saying about the Pastoral Epistles? (New York: Paulist, 2001) 11) to have secured the pseudonymity paradigm for the Pastorals. 